ment (pp. $34+4$ pl. ; Cardiff: the Museum, 1952). It reveals the many facets of the intense vitality of this Museum, not the least being the large amount of advice on technical matters given by the staff. In geology, advice to various Ministries and other organizations was given on thirty-nine occasions, involving a total of eighty-one hours of work. In botany, 1,078 determinations were made for member of the general public, and 115 inquiries dealt with. The Zoological Department dealt with 370 inquiries, of which 158 were concerned with the identification of specimens and 212 with the preservation of material, economic problems, and advice on students' theses. In the Department of Archæology a total of 457 individual inquiries were dealt with, either verbally or by correspondence. This included 262 inquiries on numismatics, involving 448 identifications. In addition, thirteen special reports were prepared in response to requests for technical information. A total of 493 inquiries were dealt with at the Welsh Folk Museum. This is an impressive record and an indication of the valuable part played by the National Museum in the communal life of the Welsh.

\section{Leeds City Museums}

The Committee of the Leeds City Museum has issued a handy guide-book to the collections and their display at the moderate price of $6 d$. A historical introduction concerning the Museum is followed by notes on animal characteristics and by a description of the four bays in the main gallery devoted to the natural history of Yorkshire. The guide-book concludes with references to the cases illustrating the story of man and some special exhibits mainly of local interest. It is well illustrated with photographs and pencil sketches of Yorkshire scenery.

\section{Exhibition of X-ray Crystallographic Equipment}

THE X-ray Analysis Group of the Institute of Physics will hold its autumn conference in London during November 20-21, and an exhibition of X-ray diffraction equipment will be an important feature of it. Offers of exhibits are invited under two headings : (a) apparatus commercially available in Great Britain, and $(b)$ examples of recent developments in X-ray crystallographic equipment that have been made in universities and other research centres in Britain. Examples of the kind of exhibit envisaged are : X-ray tubes, diffraction cameras of all types, microbeam techniques, counters and counter-spectrometers for diffraction work, aids to interpretation, monochromators, microdensitometers, travelling microscopes, X-ray films and photographic accessories, and spectrometers for fluorescent analysis. Owing to the limited space available, a selection will have to be made from the offers submitted. Offers of exhibits giving details of approximate bench and floor space required and of any services needed should be submitted before September 1 to the Conference Secretary, Mr. H. J. Goldschmidt, c/o Institute of Physics, 47 Belgrave Square, London, S.W.1.

Institute of Metal Finishing : Officers for 1953-54

THE following have been elected officers of the Institute of Metal Finishing for 1953-54: President, Dr. J. W. Cuthbertson; Vice-Presidents, Dr. S. G. Clarke, Dr. G. E. Gardam, R. A. F. Hammond, Dr. T. P. Hoar, F. Mason, R. W. Nicol, E. A. Ollard and
C. Wharrad; Honorary Secretary, Dr. S. Wernick ; and Honorary Treasurer, F. L. James.

\section{Announcements}

Emeritus Prof. W. L. Waterhouse has been elected an honorary life member of the Australian Institute of Agricultural Science in recognition of his outstanding contributions to agricultural science in Australia. Prof. Waterhouse recently retired from the position of research professor in the Faculty of Agriculture, University of Sydney.

The Research Fund of the Chemical Society provides grants for the assistance of research in all branches of chemistry. About $£ 700$ a year is available for this purpose, the income being derived from a donation of the Worshipful Company of Goldsmiths, from the Perkin Memorial Fund, and from other sources. Applications for grants should be submitted to the General Secretary, Chemical Society, Burlington House, Piccadilly, London, W.1, on the appropriate form not later than November 14.

THE Universities Federation for Animal Welfare is holding a summer school during September 19-26 at Westham House, Barford, Warwick. The school will consist of a number of lectures on various aspects of animal welfare, together with films, excursions, etc. ; at the same time the Veterinary Section of the Federation will be holding its annual general meeting. The fee for the course is 5 guineas ( 3 guineas for students). Further details can be obtained from any branch secretary of the Federation or from Miss M. P. Williams, Branch Organizer, UFAW, 7 Red Lion Square, London, W.C.1.

Tex Atomic Energy Research Establishment, Harwell, is organizing the seventh of its specialized courses on the design, use and maintenance of electronic instruments used in nuclear physics, radiochemistry and work with radioisotopes, all the subjects dealt with being entirely unclassified. The course will be held during September 28-October 2 at the Isotope School (which is outside the security fence), and applications are invited from physicists and electronic engineers holding a degree or equivalent qualification. The course is limited to twelve persons and costs 12 guineas; board and lodging can be provided at a charge of 7 guineas. Application forms (to be completed by September 11) and further information can be obtained from the Electronics Division, A.E.R.E., Harwell, near Didcot, Berks.

THe Institute of Personnel Management, in collaboration with the Personnel Management Branch of the Ministry of Labour, is organizing a five-day residential study-course on "Employment and Welfare", to be held at the Coburg Court Hotel, Bayswater Road, London, W.2, during September 6-11. The course, which is limited to twenty persons, is designed for personnel officers and others who are responsible for such matters as recruitment, selection, personnel records and welfare services. The fees are 10 guineas for the course (9 guineas to members of the Institute) and $f 8$ 15s. for board and lodging. Registration forms, to be completed as soon as possible, and further information can be obtained from the Courses Secretary, Institute of Personnel Management, Management House, 8 Hill Street, London, W.1. 